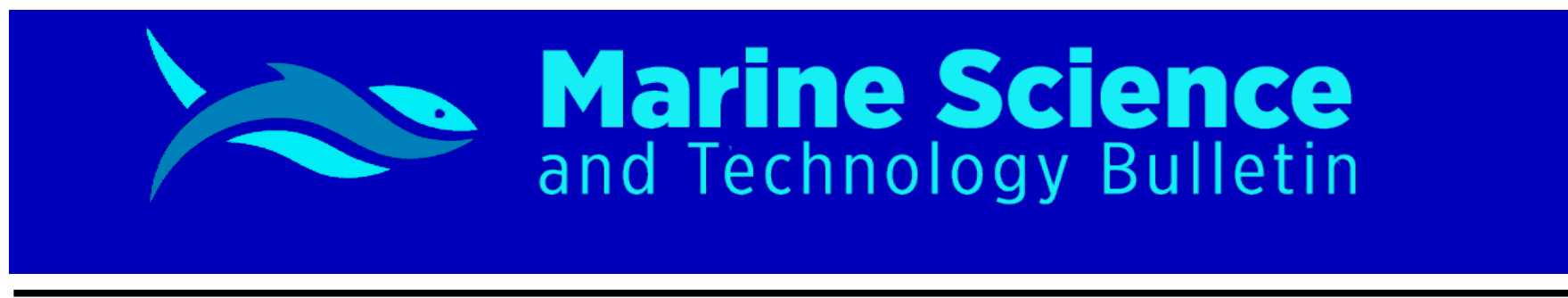

RESEARCH ARTICLE

\title{
Investigation of Heavy Metal Content of Tellina (Donax trunculus Linnaeus, 1758) in Black Sea Region (Kefken)
}

\author{
Evren $\operatorname{Tan}^{1}\left(\mathbb{D} \cdot\right.$ Bayram Kizılkaya ${ }^{2^{*}}$ \\ ${ }^{1}$ Çanakkale Onsekiz Mart University, Graduate School of Natural and Applied Sciences, Department of Aquaculture, Çanakkale, Turkey \\ ${ }^{2}$ Çanakkale Onsekiz Mart University, Faculty of Marine Sciences and Technology, Department of Aquaculture, Çanakkale, Turkey
}

\section{ARTICLE INFO}

Article History:

Received: 13.11.2019

Received in revised form: 04.12.2019

Accepted: 06.12.2019

Available online: 10.12.2019

Keywords:

Donax trunculus

Heavy metal

ICP-OES

\begin{abstract}
A B S T R A C T
In this study, monthly change of the heavy metal composition of tellina (Donax trunculus Linnaeus, 1758) from Kefken territory on the Black Sea coast between 2013 and 2014 was investigated. Heavy metal analysis was determined by ICP-OES. Mercury (Hg) and tin (Sn) were not detected during the period of 12 months. Lead $(\mathrm{Pb})$ was detected in November, December, January, February, and March and it was calculated as $12.97 \mu \mathrm{g} / \mathrm{g}$ on average. The highest amount of lead was detected in December as $16.08 \pm 0.82 \mu \mathrm{g} / \mathrm{g}$. The amounts of cadmium $(\mathrm{Cd})$, cobalt $(\mathrm{Co})$ and nickel (Ni) were determined between November and April and it was seen that they had average values such as $0.45 \mu \mathrm{g} / \mathrm{g} \mathrm{Cd}, 0.91 \mu \mathrm{g} / \mathrm{g}$ Co and $4.46 \mu \mathrm{g} / \mathrm{g}$ Ni. Chrome was detected during the 12 months and it was calculated as $4.19 \mu \mathrm{g} / \mathrm{g}$ on average. The highest and the lowest amounts of chrome were detected in January as $16.71 \pm 2.11$ and August as $0.70 \pm 0.05$, respectively. In addition, it was seen that during the period this study was held, between 2013 and 2014, there were dramatic temperature changes and the instant temperature changes positively affected the accumulation of heavy metal in the species. Despite the fact that the instant temperature changes positively affect the accumulation of heavy metals in the live metabolism, it is better to handle the subject regarding the effects of global warming on living things. It is possible to say that tellina can be consumed as food in convenient times. In respect of the detections in this study, it can be said that tellina can be conveniently consumed between April and October depending on the territory.
\end{abstract}

Please cite this paper as follows:

Tan, E., Kizılkaya, B. (2019). Investigation of Heavy Metal Content of Tellina (Donax trunculus Linnaeus, 1758) in Black Sea Region (Kefken). Marine Science and Technology Bulletin, 8(2): 69-75.

\section{Introduction}

Due to the population growth worldwide, the increase of need for protein results in the increase of consumption of food from animal origin. Therefore, seafood stands out as a way of providing animal source foods of high quality. Within seafood, bivalve emerges as an important food resource with its recently increasing consumption in our country. United Nations and World Food Programme declared that seafood is going to have an important role in food supply in future due to the population growth which is estimated to increase up to 9 billion in 2050. So, it is assumed that the growth in the industry of seafood is going to continue in an accelerating way (FAO, 2015).

\footnotetext{
* Corresponding author

E-mail address: bayram342001@yahoo.com (B. Kizılkaya)
} 
Unlike the other countries, the production of seafood in Turkey relies on fish production especially in aquaculture. Even though our country, which is surrounded on three sides by the sea, has so many economic bivalve species such as Mediterranean mussel (Mytilus galloprovincialis Lamarck, 1819), flat osyter (Ostrea edulis Linnaeus, 1758), sand mussel (Ruditapes decussatus Linnaeus, 1758), white clam (Chamelea gallina Linnaeus, 1758), sea scallop (Pecten maximus Linnaeus, 1758) and tellina (Donax trunculus Linnaeus, 1758); the production of these species, which are rich in essential amino acids, unsaturated fatty acids, vitamins, minerals and antioxidant materials, is lower than its real potential. Especially the aquaculture production is so low that it is limited with Mediterranean mussel solely (Karayücel et al., 2010; Acarlı et al., 2011). However; it is essential to ascend the production and hunting rate of these species and to show their nutritious capacity and meat yield. Pouring the sewage and transmission of pesticides to sea, industrial and domestic waste, acid rains, heavy seaway and the harmful waste left from ships result in the increase of heavy metals such as cadmium, lead, copper, zinc, mercury, arsenic and seafood takes in all these heavy metals. However, consumption of these foods harm human health ( $\mathrm{Hu}, 2000$; Otchere, 2004; Guidi et al., 2010; Kayhan et al., 2009; Le et al., 2011). In the related studies, bivalve species is preferred both because of its common consumption and its being indicator species in sea pollution (Sericano, 2000; Conti and Cecchetti, 2003; Casas et al., 2008; Başçınar, 2009). A study based on the heavy metal content of Mediterranean mussels taken from 10 different parts of Ionian Sea shows that the samples involve $1.19 \mathrm{mg} / \mathrm{lt} \mathrm{lead,} 0.31 \mathrm{mg} / \mathrm{lt}$ chrome, $0.15 \mathrm{mg} / \mathrm{lt}$ mercury, 0.64 $\mathrm{mg} / \mathrm{lt} \mathrm{cadmium,} 0.54 \mathrm{mg} / \mathrm{lt}$ tin and $5.15 \mathrm{mg} / \mathrm{lt}$ zinc (Storelli et al., 2000). In another study on mussels taken from Annaba Bay, Algeria shows that the mussels taken from four different stations involve $0.35 \mathrm{mg} / \mathrm{kg}$ cadmium, $0.81 \mathrm{mg} / \mathrm{kg}$ chrome, $9.52 \mathrm{mg} / \mathrm{kg}$ copper, $0.198 \mathrm{mg} / \mathrm{kg}$ silver, $7.73 \mathrm{mg} / \mathrm{kg}$ manganese, $2.01 \mathrm{mg} / \mathrm{kg}$ lead, and $83.33 \mathrm{mg} / \mathrm{kg}$ zinc respectively but iron and nickel were not detected (Belabed et al., 2013). Usero et al. (2005) declared that their study upon the heavy metal concentration of tellina and white clam taken from Atlantic shores of South Spain showed that tellina involved high amounts of chrome, copper, lead, zinc, arsenic and silver and white clam also involved high amounts of nickel and cadmium. Maanan (2008) studied cadmium, chrome, lead, and manganese concentration of Mediterranean mussel, pacific oyster (Crassostrea gigas Thunberg, 1973) and grooved carpet shell (Venerupis decussatus Linnaeus, 1758) taken from Atlantic shores of Morocco and declared that these elements arose in spring and summer but they declined in winter and these results coincide with the results of Mubiana et al. (2005). Conti and Cecchetti (2003) declared that Mediterranean mussels taken from Sicily shores of Italy did not pose danger in respect of the elements cadmium, chrome, copper, silver and zinc and they were suitable for consumption. Yildiz et al. (2011) investigated seasonal variation in the condition index, meat yield and biochemical composition of the flat oyster Ostrea edulis collected from the Dardanelles. De Souza et al. (2016) studied arsenic, lead, nickel, and cadmium content of pacific oyster and mussels taken from 28 aquaculture plants in the north and south bays of Santa Catarina, Brazil and declared that the samples of plants in the south bay involved arsenic and the samples of plants in the north bay involved nickel highly; yet, both of them involved low amounts lead and cadmium.

In this study, the convenient consumption time of tellina from Kefken, and its heavy metal accumulation change due to seasonal temperatures were examined.

\section{Material and Methods}

\section{Collection of the Samples}

Tellina (Donax trunculus Linnaeus, 1758) were collected from the Kefken station (Figure 1) between November 2013 and October 2014, monthly. 50 samples of the species were provided every month.

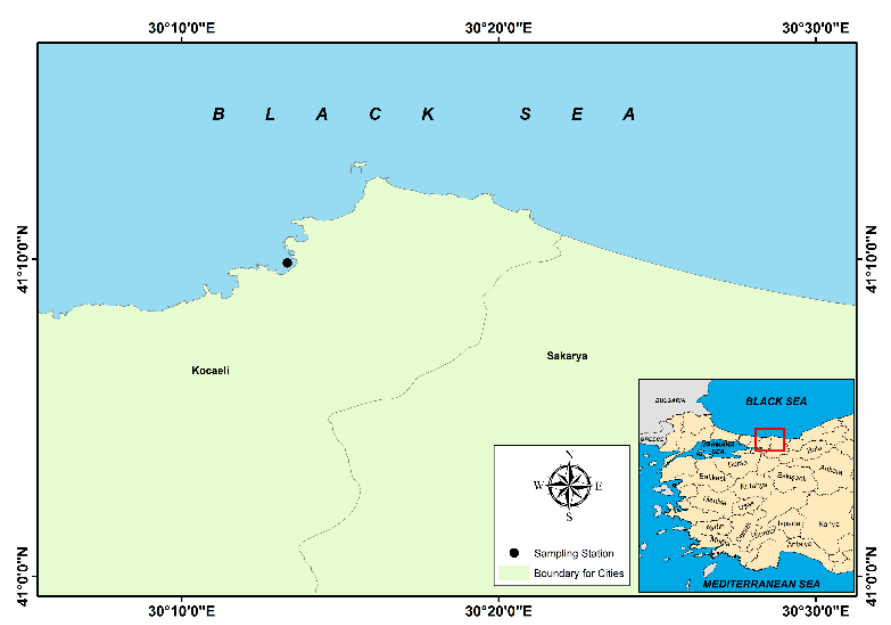

Figure 1. Sampling area of tellina and Kefken station

\section{Determination of Heavy Metal Content}

The samples were homogenized and dried for 72 hours at $105^{\circ} \mathrm{C}$. All analyzes in this study were performed on dry samples. The analysis of heavy metal contents was made in Tekirdağ Namı Kemal University Central Laboratory (NABILLTEM). Spectro Blue brand ICPOES was used for element determination and Novawave SA brand was used for the preparation of the samples in NABILLTEM.

Digestion Procedure for Heavy Metal Analysis of Donax

\section{trunculus by ICP-OES}

In order to determine heavy metal contents of the samples, a digestion procedure and solubilization of the samples were chosen and used Aydin (2008). Therefore, microwave digestion was used and performed with nitric acid in NABILLTEM. Firstly, the samples were dissolved by microwave digestion with acid. The samples were then allowed to cool and made ready for ICP-OES by filtration with distilled water. This procedure was repeated twice for each sample. The minerals ( $\mathrm{Pb}, \mathrm{Cd}, \mathrm{Cr}, \mathrm{Co}, \mathrm{Ni}, \mathrm{Hg}$ and $\mathrm{Sn}$ ) were measured with ICPOES and then concentrations were calculated based on the standards.

\section{Monitoring of Environmental Parameters}

Temperature and salinity of the sea water taken from the research area between November 2013 and October 2014 were measured with YSI probe. 


\section{Results and Discussion}

The heavy metal contents of Donax trunculus between November and October are given in Table 1. The temperature and salinity parameters of sea water in Kefken region are shown in Figure 2. In Figure 3, the average air temperatures in Turkey on climate assessment reports that were prepared by T.C. the General Directorate of Meteorology of the Ministry of Forestry and Water Affairs for 2013 and 2014 are given (OSİB1 2013; OSİB1 2014). The amount of lead was found between November and March, but was not determined in other months. The highest lead was found to be as $16.08 \pm 0.82 \mu \mathrm{g} / \mathrm{g}$ in December. It is observed that the most suitable months of consumption of the species in respect of lead content are between April and October. The fact that the determination of lead was not determined after April does not mean that the lead and heavy metals do not exist. This is related to the detection limit of the ICP-OES instrument. In other words, the results from ICP-OES instrument can be obtained if the heavy metals in the samples are at a level that can be detected. The samples are diluted at a concentration at which the instrument can read all the elements during the sample preparation and microwave digestion. When the dilution is made during sample preparation, some elements can be measured or not by ICP-OES instrument if the samples are at a level concentration in liquid phase. Therefore, the fact that the detection of some elements in the samples was not determined in some months does not mean that these heavy metals do not exist. The limit of detection of the lead which depends on the dilution factor of 100 times is about $4 \mu \mathrm{g} / \mathrm{g}$ on dry weight. In other words, the reason why the amount of lead and other heavy metals cannot be determined in some samples or months by ICP-OES, can be explained as the detection limit of the instrument for $\mathrm{Pb}$ is about $4 \mathrm{ng}$ / $\mathrm{mL}(0.04 \mu \mathrm{g} / \mathrm{mL})$ in the dissolved liquid phase. Then, the amount determined in the liquid phase by instrument is regulated by the dilution coefficient to detect the actual amount of heavy metal in the dry sample. Therefore, some elements in the samples could not be determined in some months due to the digestion procedure, liquid dilution and detection limit. Figure 2 shows that the temperatures of seawater in the sample area have increased since March 2014. The temperatures were high in August 2014, and also it was seen that the temperature in September and October 2014 was approximately $5{ }^{\circ} \mathrm{C}$ warmer than the previous November 2013. As shown in Figure 3, the climate assessment report of 2013 and 2014 prepared by T.C. the General Directorate of Meteorology of the Ministry of Forestry and Water Affairs shows that the temperature changes between October and November in 2014 were higher than the same months of 2013. In other words, it is seen that there was a change of $6.5^{\circ} \mathrm{C}$ in the same months of 2014 while there was a change of about $3{ }^{\circ} \mathrm{C}$ between October and November in 2013. It can be said that these snap temperature changes between seasons also affected the heavy metal accumulation of the species. The amount of lead and other heavy metal was not determined since April in 2014. It is thought to be related to the differences in the nutrients and components in marine environment due to the temperature changes between 2014 and 2013. Cadmium was detected between November and May and was not determined in the other months. Cobalt and nickel like cadmium were also determined in the same months. The chromium amount of the species showed that it was high between November and May but decreased in the following months. The detection limit of chromium by ICP-OES is lower than the other elements and therefore it can be said that it is easily determined. The results of chromium indicate that the other metals decreased in April and October. The reason why the other heavy metals cannot be determined during these months has been explained in detail above. It is known that these species feed filtration of sea water. Therefore, the changes in the temperature and the related components in the sea water can lead to differences in the accumulation of heavy metals. It can be said that studies like this clearly present the effects of global warming on environmental conditions and living things.

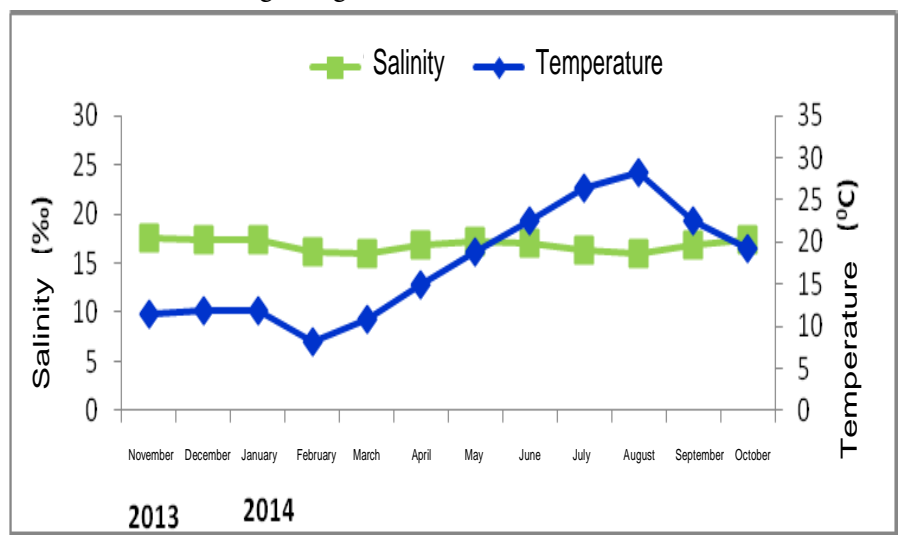

Figure 2. Sea water temperature and salinity parameters between November 2013 and October 2014 in Kefken region

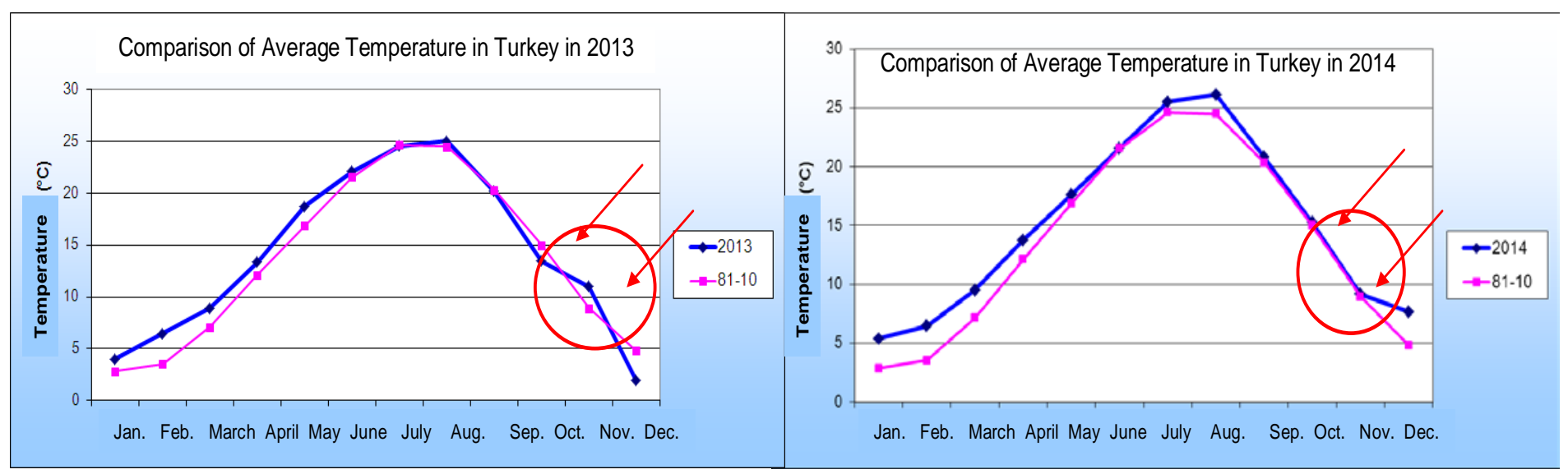

Figure 3. Change of average temperatures in Turkey between 2013 and 2014 (OSİB1 2013; OSİB1 2014) 
Table 1. Monthly heavy metal contents of tellina (Donax trunculus Linnaeus, 1758) on dry weight

\begin{tabular}{|c|c|c|c|c|c|c|}
\hline Heavy Metals & November & December & January & February & March & April \\
\hline $\mathrm{Pb}(\mu \mathrm{g} / \mathrm{g})$ & $12.59 \pm 3.55$ & $16.08 \pm 0.82$ & $8.27 \pm 0.71$ & $14.06 \pm 2.61$ & $13.83 \pm 0.63$ & N.D. \\
\hline $\mathrm{Cd}(\mu \mathrm{g} / \mathrm{g})$ & $0.31 \pm 0.02$ & $0.33 \pm 0.01$ & $1.07 \pm 0.06$ & $0.25 \pm 0.11$ & $0.32 \pm 0.00$ & $0.52 \pm 0.15$ \\
\hline $\mathrm{Cr}(\mu \mathrm{g} / \mathrm{g})$ & $3.12 \pm 0.24$ & $6.84 \pm 0.72$ & $16.71 \pm 2.11$ & $3.64 \pm 0.89$ & $9.91 \pm 0.96$ & $2.46 \pm 1.44$ \\
\hline Co $(\mu \mathrm{g} / \mathrm{g})$ & $0.61 \pm 0.03$ & $0.81 \pm 0.11$ & $1.68 \pm 0.19$ & $0.84 \pm 0.05$ & $1.03 \pm 0.05$ & $0.46 \pm 0.08$ \\
\hline $\mathrm{Ni}(\mu \mathrm{g} / \mathrm{g})$ & $2.66 \pm 0.30$ & $3.97 \pm 0.02$ & $14.92 \pm 0.95$ & $3.16 \pm 0.01$ & $5.36 \pm 0.51$ & $0.62 \pm 0.72$ \\
\hline $\mathrm{Hg}(\mathrm{ng} / \mathrm{g})$ & N.D. & N.D. & N.D. & N.D. & N.D. & N.D. \\
\hline Sn (ng/g) & N.D. & N.D. & N.D. & N.D. & N.D. & N.D. \\
\hline Heavy Metals & May & June & July & August & September & October \\
\hline $\mathrm{Pb}(\mu \mathrm{g} / \mathrm{g})$ & N.D. & N.D. & N.D. & N.D. & N.D. & N.D. \\
\hline $\mathrm{Cd}(\mu \mathrm{g} / \mathrm{g})$ & $0,38 \pm 0,07$ & N.D. & N.D. & N.D. & N.D. & N.D. \\
\hline $\operatorname{Cr}(\mu \mathrm{g} / \mathrm{g})$ & $2,54 \pm 0,06$ & $1,44 \pm 0,05$ & $1,38 \pm 0,01$ & $0,70 \pm 0,05$ & $0,80 \pm 0,05$ & $0,71 \pm 0,00$ \\
\hline Co $(\mu \mathrm{g} / \mathrm{g})$ & N.D. & N.D. & N.D. & N.D. & N.D. & N.D \\
\hline $\mathrm{Ni}(\mu \mathrm{g} / \mathrm{g})$ & $0,51 \pm 0,00$ & N.D. & N.D. & N.D. & N.D. & N.D. \\
\hline $\mathrm{Hg}(\mathrm{ng} / \mathrm{g})$ & N.D. & N.D. & N.D. & N.D. & N.D. & N.D. \\
\hline Sn (ng/g) & N.D. & N.D. & N.D. & N.D. & N.D. & N.D. \\
\hline
\end{tabular}

Note: ${ }^{\star}$ N.D. indicates that the measurements with ICP-OES are below the detection limit

Table 2. Heavy metal research in different bivalve

\begin{tabular}{|c|c|c|c|c|c|}
\hline Sample Type & Elements & Location of Sample & Digestion Method & Instrument & Reference \\
\hline $\begin{array}{l}\text { D. trunculus } \\
\text { C. gallina }\end{array}$ & $\begin{array}{l}\mathrm{Cr}, \mathrm{Ni}, \mathrm{Cu}, \mathrm{Cd}, \mathrm{Pb} \\
\mathrm{Zn}, \mathrm{As}, \mathrm{Hg}\end{array}$ & $\begin{array}{l}\text { Southern Spain, } \\
\text { Atlantic coast }\end{array}$ & Microwave digestion & AAS & Usero et al.(2005) \\
\hline C. gallina & $\begin{array}{l}\mathrm{Zn}, \mathrm{Cd}, \mathrm{Cu}, \mathrm{Pb}, \mathrm{Fe} \\
\mathrm{Ni}, \mathrm{Cr}, \mathrm{Mn}, \mathrm{As}, \mathrm{Hg}\end{array}$ & $\begin{array}{l}\text { Southern Spain, } \\
\text { Atlantic coast }\end{array}$ & Microwave digestion & AAS, GFAAS & Usero et al.(2008) \\
\hline $\begin{array}{l}\text { D. trunculus } \\
\text { C. gallina }\end{array}$ & $\begin{array}{l}\mathrm{Hg}, \mathrm{Cd}, \mathrm{Pb}, \mathrm{Cu}, \mathrm{Zn} \text {, } \\
\mathrm{As}, \mathrm{Fe}, \mathrm{Co}, \mathrm{Al}, \mathrm{Mn}, \\
\mathrm{Ni}, \mathrm{Sn}, \mathrm{Cr}\end{array}$ & $\begin{array}{l}\text { Tekirdağ, North } \\
\text { Marmara }\end{array}$ & Microwave digestion & ICP-MS & Özden et al. (2009) \\
\hline $\begin{array}{l}\text { R. decussatus } \\
\text { R. philippinarum }\end{array}$ & $\begin{array}{l}\mathrm{Cr}, \mathrm{Ni}, \mathrm{Cu}, \mathrm{Zn}, \mathrm{As} \\
\mathrm{Cd}, \mathrm{Pb}, \mathrm{Hg}\end{array}$ & Northwest Portugal & Wet digestion & ICP-MS & Figueria and Freitas (2013) \\
\hline $\begin{array}{l}\text { M. galloprovincialis } \\
\text { C. glabra }\end{array}$ & $\mathrm{Cd}, \mathrm{Cu}, \mathrm{As}, \mathrm{Hg}, \mathrm{Pb}$ & $\begin{array}{l}\text { Ionian Sea Mar Piccolo, } \\
\text { Taranto, Navy Arsenal }\end{array}$ & Microwave digestion & ICP-MS & Giandomenico et al. (2015) \\
\hline $\begin{array}{l}\text { C.grayanus } \\
\text { C. gigas }\end{array}$ & $\mathrm{Zn}, \mathrm{Cu}, \mathrm{Cd}, \mathrm{Pb}, \mathrm{Ni}$ & $\begin{array}{l}\text { Japan Amurskiy and } \\
\text { Ussuriyskiy Gulfs }\end{array}$ & Wet digestion & FAAS & Shulkin et al. (2003) \\
\hline $\begin{array}{l}\text { C. gigas } \\
\text { M. edulis }\end{array}$ & $\mathrm{Cd}, \mathrm{Pb}, \mathrm{Cu}, \mathrm{Zn}$ & $\begin{array}{l}\text { South West England, } \\
\text { Kent, Shell Ness, Long } \\
\text { Rock, Epple Blind-Fez, } \\
\text { Nayland Rock, Foreness } \\
\text { Point, Pegwell }\end{array}$ & Microwave digestion & ICP-OES & Bray et al. (2015) \\
\hline D. trunculus & $\begin{array}{l}\mathrm{Fe}, \mathrm{Mn}, \mathrm{Zn}, \mathrm{Cu}, \mathrm{Pb} \\
\text { and } \mathrm{Cd}\end{array}$ & Nile River Delta & Wet digestion & AAS & El-Serehy et al. (2012) \\
\hline M. galloprovincialis & $\begin{array}{l}\mathrm{Ag}, \mathrm{Al}, \mathrm{As}, \mathrm{Cd}, \mathrm{Co}, \\
\mathrm{Cr}, \mathrm{Cu}, \mathrm{Fe}, \mathrm{K}, \mathrm{Mn} \text {, } \\
\mathrm{Ni}, \mathrm{Pb}, \mathrm{Sn}, \mathrm{V} \text {, and } \\
\mathrm{Zn}\end{array}$ & $\begin{array}{l}\text { Black Sea, Marmara Sea, } \\
\text { Turkish Straits, Aegean } \\
\text { Sea }\end{array}$ & Microwave digestion & ICP-MS & Belivermiş et al. (2016) \\
\hline M. galloprovincialis & $\begin{array}{l}\mathrm{Cr}, \mathrm{Mn}, \mathrm{Ni}, \mathrm{Mg}, \mathrm{Fe} \\
\mathrm{Cu}, \mathrm{Zn}, \mathrm{Se}\end{array}$ & North Adriatic Sea & Microwave digestion & ICP-MS & Bongiorno et.al. (2015) \\
\hline Ostrea edulis & $\begin{array}{l}\mathrm{Hg}, \mathrm{Cd}, \mathrm{Cu}, \mathrm{Zn}, \mathrm{Pb} \\
\mathrm{Mn}, \mathrm{As}, \mathrm{Se}, \mathrm{Cr}\end{array}$ & $\begin{array}{l}\text { A local fish market in } \\
\text { İstanbul }\end{array}$ & Microwave digestion & ICP-MS & Erkan et.al. (2011) \\
\hline
\end{tabular}

\section{Discussion}

Tellina lives in fine sand with tidal traffic and heavy wave actions without precipitate segregation (Brown and McLachlan, 1990; Gaspar et al., 1999). In addition; among the other bivalves, tellina is one of the most dominant species worldwide and they live under $15-20 \mathrm{~cm}$ of the sand surface (Ansell, 1983). It generally prefers 0-2 meters of depth (Ansell and Lagardère, 1980); however, it is possible to see up to 6 meters of depth (Gaspar et al., 1999). D. trunculus has a smooth surface with radial vessels and its shell is either yellowish or light brown. Inside of the shell, there is coloration of blue-purple or brownish and orange depending on the territory. Its length is generally $30 \mathrm{~mm}$; yet, it may reach up to $45 \mathrm{~mm}$ (Poppe and Goto, 1993; Öztürk et al., 2014).

The changes of element content may take place because of metabolic activities due to the season and seasonal differences in the chemical properties of sea water (Karayakar et al., 2007); studies of 
Astorga-Espana et al. (2007) and Li et al. (2010) showed that lead (0.14$0.18 \mathrm{mg} / \mathrm{kg})$ and cadmium $(0.25-0.48 \mathrm{mg} / \mathrm{kg})$ content of the thickshelled mussels were below the maximum limits of European Union (1.5 mg/kg for lead; $1 \mathrm{mg} / \mathrm{kg}$ for cadmium) and Cr $(0.13-0.19 \mathrm{mg} / \mathrm{kg})$ and $\mathrm{Cu}(1.3-3.8 \mathrm{mg} / \mathrm{kg})$ were below the maximum limits too. Lead and Cd concentration of Mytilus edulis was 162 and $0.82 \mathrm{mg} / \mathrm{kg}$ respectively (Olafsson, 1986), 21 and $4 \mathrm{mg} / \mathrm{kg}$ in Mytilus galloprovincialis in Çam Bay of East Black Sea (Cevik et al., 2008) and 15.7 , and $0.168 \mathrm{mg} / \mathrm{kg}$ in Mytilus chilensis (Astorga-Espana et al., 2007). Nickel and cadmium concentration of Mytilus galloprovincialis in Çam Bay was 6 and $3 \mathrm{mg} / \mathrm{kg}$ respectively (Cevik et al., 2008). These kind of samples are collected from sea, dried by lyophilisation or stove (generally in $110^{\circ} \mathrm{C}$ ) and stabilized, and solubilized with acid or acid mixtures by the methods of wet decomposition, dry-ashing, or microwave methods. Heavy metals solubilized in the samples are assessed by spectroscopic methods such as flame atomic absorption (FAAS), graphite furnace atomic absorption (GFAAS), inductively coupled plasma atomic emission (ICP-AES), inductively coupled plasma-mass emission (ICP-MS), and inductively coupled plasmaoptic emission (ICP-OES). Some studies related to these samples are given in Table 2.

According to the declaration (2008-29) of Ministry of Agriculture and Forestry on the standards of quality of shell fishes; the amounts must be lower than $1.2 \mathrm{mg} / \mathrm{lt}$ for tin and tin compounds, $0.1 \mathrm{mg} / \mathrm{lt}$ for nickel and nickel compounds, $0.1 \mathrm{mg} / \mathrm{lt}$ for lead and lead compounds, $3 \mathrm{mg} / \mathrm{lt}$ for boron, $0.1 \mathrm{mg} / \mathrm{lt}$ for chrome, $0.7 \mathrm{mg} / \mathrm{lt}$ for iron, $0.003 \mathrm{mg} / \mathrm{lt}$ for zinc, $0.1 \mathrm{mg} / \mathrm{lt}$ for arsenic, $0.07 \mathrm{mg} / \mathrm{lt}$ for aluminium, $1 \mathrm{mg} / \mathrm{lt}$ for bromine, $0.01 \mathrm{mg} / \mathrm{lt}$ for copper, $5 \mathrm{mg} / \mathrm{lt}$ barium, $0.015 \mathrm{mg} / \mathrm{lt}$ for beryllium, and $1 \mathrm{mg} / \mathrm{lt}$ for cobalt.

\section{Conclusion}

In this study, monthly changes of heavy metal composition of tellina (Donax trunculus Linnaeus, 1758) in Kefken region of Kocaeli and the effects of seasonal temperatures on accumulation were investigated. $\mathrm{Hg}$ and $\mathrm{Sn}$ were not detected as heavy metal pollutant, but $\mathrm{Pb}$ was determined in November, December, January, February and March and the average amount was determined as $12.97 \mu \mathrm{g} / \mathrm{g}$. The average amount of Cd, Cr, Co and Ni was determined as $45 \mu \mathrm{g} / \mathrm{g}, 4.19$ $\mu \mathrm{g} / \mathrm{g}, 0.91 \mu \mathrm{g} / \mathrm{g}$ and $4.46 \mu \mathrm{g} / \mathrm{g}$, respectively. It was seen that the temperature changes between 2014 and 2013 were approximately $3.5^{\circ} \mathrm{C}$. It was determined that these snap temperature changes between seasons had an effect on the metal accumulation of the living species. Although the snap temperature difference seems to have a positive effect on living metabolism, it would be more appropriate to evaluate the effect of this situation on all natural organisms. This study presents important results such as other literature. Therefore, it can be said that D. trunculus is a suitable species for human consumption. It is thought that $D$. trunculus species will be suitable for consumption between April and October.

\section{Acknowledgments}

This article was written within the scope of Evren Tan's Ph.D. thesis.

\section{Conflict of Interest}

The authors declare that there is no conflict of interest.

\section{References}

Acarl, S., Lok, A., Kücükdermenci, A., Yildiz, H. \& Serdar, S. (2011). Comparative growth, survival and condition index of flat oyster, (Ostrea edulis, Linnaeus 1758) in Mersin Bay, Aegean Sea, Turkey. Kafkas Universitesi Veteriner Fakultesi Dergisi, 17(2): 203-210. https://doi.org/10.9775/kvfd.2010.2806

Ansell, A.D. (1983). The biology of the genus Donax. p. 607-635. In: McLachlan, A., Erasmus, T. (eds.) Developments in hydrobiology (vol 19): Sandy beaches as ecosystems. Springer, Dordrecht. $757 \mathrm{p}$.

Ansell, A.D. \& Lagardere, F. (1980). Observations on the biology of Donax trunculus and Donax vittatus at Ile d'Oleron (French Atlantic Coast). Marine Biology, 57(4): 287-300. https://doi.org/10.1007/BF00387572

Astorga-Espana, M.S., Rodriguez-Rodriguez, E.M. \& Diaz Romero, C. (2007). Comparison of mineral and trace element concentrations in two molluscs form the Strait of Magellan (Chile). Journal of Food Composition and Analysis, 20(3-4): 273-279. https://doi.org/10.1016/j.jfca.2006.06.007

Aydin, I. (2008). Comparison of dry, wet and microwave digestion procedures for the determination of chemical elements in wool samples in Turkey using ICP-OES technique. Microchemical Journal, $\quad \mathbf{9 0}(1)$ : $\quad 82-87$. https://doi.org/10.1016/j.microc.2008.03.011

Başçınar, N.S. (2009). Bentik Canlılar ve Biyoindikatör Tür. SÜMAE Yunus Araştırma Bülteni, 9(1): 5-8.

Belabed, B.E., Laffray, X., Dhib, A., Fertouna-Belakhal, M., Turki, S. \& Aleya, L. (2013). Factors contributing to heavy metal accumulation in sediments and in the intertidal mussel Perna perna in the Gulf of Annaba (Algeria). Marine Pollution Bulletin, 74(1): 477-489. https://doi.org./10.1016/j.marpolbul.2013.06.004

Belivermiş, M.N., Kılıç, Ö. \& Çotuk, Y. (2016). Assessment of metal concentrations in indigenous and caged mussels (Mytilus galloprovincialis) on entire Turkish coastline. Chemosphere, 144:

1980-1987. https://doi.org/10.1016/j.chemosphere.2015.10.098

Bongiorno, T., Iacumin, L., Tubaro, F., Marcuzzo, E., Sensidoni, A. \& Tulli, F. (2015). Seasonal changes in technological and nutritional quality of Mytilus galloprovincialis from suspended culture in the Gulf of Trieste (North Adriatic Sea). Food Chemistry, 173: 355-362. https://doi.org/10.1016/j.foodchem.2014.10.029

Bray, D.J., Green, I., Golicher, D. \& Herbert, R.J.H. (2015). Spatial variation of trace metals within intertidal beds of native mussels (Mytilus edulis) and non-native Pacific oysters (Crassostrea gigas): implications for the food web? Hydrobiologia, $\quad$ 757(1): 235-249. 
Brown, A.C. \& McLachlan, A. (1990). Ecology of sandy shores. Elsevier, Amsterdam. 328p.

Casas, S., Gonzalez, J.L., Andral, B. \& Cossa, D. (2008). Relation between metal concentration in water and metal content of marine mussels (Mytilus galloprovincialis): Impact of physiology. Environmental Toxicology and Chemistry, 27(7): 1543-1552. https://doi.org/10.1897/07-418

Cevik, U., Damla, N., Kobya, A. I., Bulut, V.N., Duran, C., Dalgıc, G. \& Bozac1, R. (2008). Assessment of metal element concentrations in mussel (M. galloprovincialis) in Eastern Black Sea, Turkey. Journal of Hazardous Materials, 160(2): 396-401. https://doi.org/10.1016/j.jhazmat.2008.03.010

Conti, M.E. \& Cecchetti, G. (2003). A biomonitoring study: trace metals in algae and molluscs from Tyrrhenian coastal areas. Environmental Research, 93(1): 99-112.

De Souza, R.V., Garbossa, L.H.P., Campos, C.J.A., Vianna, L.D.N., Vanz, A. \& Rupp, G.S. (2016). Metals and pesticides in commercial bivalve mollusc production areas in the North and South Bays, Santa Catarina (Brazil). Marine Pollution Bulletin, 105(1): 377-384. https://doi.org/10.1016/j.marpolbul.2016.02.024

El-Serehy, H.A., Aboulela, H., Al-Misned, F., Kaiser, M., Al-Rasheid, K. \& El-Din, H.E. (2012). Heavy metals contamination of a Mediterranean coastal ecosystem, Eastern Nile Delta, Egypt. Turkish Journal of Fisheries and Aquatic Sciences, 12(4): 751760. https://doi.org/10.4194/1303-2712-v12 403

Erkan, N., Özden, Ö. \& Ulusoy, Ş. (2011). Seasonal micro-and macromineral profile and proximate composition of oyster (Ostrea edulis) analyzed by ICP-MS. Food Analytical Methods, 4(1): 35-40. https://doi.org/10.1007/s12161-010-9128-6

FAO. (2015). The State of Food and Agriculture: Social protection and agriculture - Breaking the cycle of rural poverty. Food and Agriculture Organızation of the United Nations. Rome. 129 pp.

Figueira, E. \& Freitas, R. (2013). Consumption of Ruditapes philippinarum and Ruditapes decussatus: comparison of element accumulation and health risk. Environmental Science and Pollution Research, 20(8): 5682-5691. https://doi.org/10.1007/s11356-013-1587-z

Gaspar, M.B., Ferreira, R. \& Monteiro, C.C. (1999). Growth and reproductive cycle of Donax trunculus L., (Mollusca: Bivalvia) off Faro, southern Portugal. Fisheries Research,. 41(3): $\quad 309-316 . \quad$ https://doi.org/10.1016/S0165$\underline{7836(99) 00017-X}$

Giandomenico, S., Cardellicchio, N., Spada, L., Annicchiarico, C. \& Di Leo, A. (2015). Metals and PCB levels in some edible marine organisms from the Ionian Sea: Dietary intake evaluation and risk for consumers. Environmental Science and Pollution Research, 23(13): 12596-12612. https://doi.org/10.1007/s11356-015-5280-2

Guidi, P., Frenzilli, G., Benedetti, M., Bernardeschi, M., Falleni, A., Fattorini, D., Regoli, F., Scarcelli, V. \& Nigro, M. (2010). Antioxidant, genotoxic and lysosomal biomarkers in the freshwater bivalve (Unio pictorum) transplanted in a metal polluted river basin. Aquatic Toxicology, 100(1): 75-83. https://doi.org/10.1016/j.aquatox.2010.07.009

Hu, H. (2000). Exposure to metals. Primary Care: Clinics in Office Practice, 27(4): 983-996. https://doi.org/10.1016/S0095$\underline{4543(05) 70185-8}$

Karayakar, F., Erdem, C. \& Cicik, B. (2007). Seasonal variation in copper, zinc, chromium, lead and cadmium levels in hepatopancreas, gill and muscle tissues of the mussel Brachidontes pharaonis Fischer, collected along the Mersin coast, Turkey. Bulletin of Environmental Contamination and Toxicology, 79(3): 350-355. https://doi.org/10.1007/s00128007-9246-Z

Karayücel, S., Çelik, M.Y., Karayücel, İ. \& Erik, G. (2010). Growth and production of raft cultivated Mediterranean mussel (Mytilus galloprovincialis Lamarck, 1819) in Sinop, Black sea. Turkish Journal of Fisheries and Aquatic Sciences, 10(1): 9-17. https://doi.org/10.4194/trjfas.2010.0102

Kayhan, F.E., Muşlu, M.N. \& Koç, N.D. (2009). Bazi ağır metallerin sucul organizmalar üzerinde yarattığı stres ve biyolojik yanitlar. Journal of Fisheries Sciences, 3(2): 153-162.

Le, T.T., Leuven, R.S. \& Hendriks, A.J. (2011). Modeling metal bioaccumulation in the invasive mussels Dreissena polymorpha and Dreissena rostriformis bugensis in the rivers Rhine and Meuse. Environmental Toxicology and Chemistry, 30(12): 2825-2830. https://doi.org/10.1002/etc.685

Li, G., Li, J. \& Li, D. (2010). Seasonal variation in nutrient composition of Mytilus coruscus from China. Journal of Agricultural and Food Chemistry, 58(13): $\quad$ 7831-7837. https://doi.org/10.1021/jf101526c

Maanan, M. (2008). Heavy metal concentrations in marine molluscs from the Moroccan coastal region. Environmental Pollution, 153(1): 176-183. https://doi.org/10.1016/j.envpol.2007.07.024

Mubiana, V.K., Qadah, D., Meys, J. \& Blust, R. (2005). Temporal and spatial trends in heavy metal concentrations in the marine mussel Mytilus edulis from the Western Scheldt estuary (The Netherlands). Hydrobiologia, 540(1-3): 169-180. https://doi.org/10.1007/s10750-004-7134-7

Olafsson, E.B. (1986). Density dependence in suspension-feeding and deposit-feeding populations of the bivalve Macoma balthica: A field experiment. The Journal of Animal Ecology, 55(2): 517-526. https://doi.org/10.2307/4735

OSİB1. (2013). Republic of Turkey, the General Directorate of Meteorology of the Ministry of Forestry and Water Affairs: Climate Assessment of 2013. Retrieved in November 7, 2019 from https://www.mgm.gov.tr

OSİB1 (2014). Republic of Turkey, the General Directorate of Meteorology of the Ministry of Forestry and Water Affairs: Climate Assessment of 2014. Retrieved in November 7, 2019 from https://www.mgm.gov.tr

Otchere, F.A. (2004). Heavy metals concentrations and burden in the bivalves (Anadara (Senilia) senilis, Crassostrea tulipa and 
Perna perna) from lagoons in Ghana: Model to describe mechanism of accumulation/excretion. African Journal of Biotechnology, 2(9): 280-287. http://dx.doi.org/10.5897/AJB2003.000-1057

Özden, Ö., Erkan, N. \& Deval, M.C. (2009). Trace mineral profiles of the bivalve species Chamelea gallina and Donax trunculus. Food Chemistry, 113(1): 222-226. https://doi.org/10.1016/j.foodchem.2008.06.069

Öztürk, B., Topaloğlu, B. \& Topçu, N.E. (2014). Su Omurgasızları Laboratuvar Kılavuzu, İstanbul Üniversitesi, Su Ürünleri Fakültesi. 59p.

Poppe, G.T. \& Goto, Y. (1993), European Seashells Volume II (Scaphopoda, Bivalvia, Cephalopoda). Hemmen, Wiesbaden Allemagne, 221p.

Sericano, J.L. (2000). The Mussel Watch approach and its applicability to global chemical contamination monitoring programmes. International Journal of Environment and Pollution, 13(1-6): 340-350. https://doi.org/10.1504/IJEP.2000.002323

Shulkin, V.M., Presley, B.J. \& Kavun, V.la. (2003). Metal concentrations in mussel Crenomytilus grayanus and oyster Crassostrea gigas in relation to contamination of ambient sediments. Environment International, 29(4): 493-502. https://doi.org/10.1016/S0160-4120(03)00004-7

Storelli, M.M., Storelli, A. \& Marcotrigiano, G.O. (2000). Heavy metals in mussels (Mytilus galloprovincialis) from the Ionian Sea, Italy. Journal of Food Protection, 63(2): 273-276.

Usero, J., Morillo, J. \& El Bakouri, H. (2008). A general integrated ecotoxicological method for marine sediment quality assessment: Application to sediments from littoral ecosystems on Southern Spain's Atlantic coast. Marine Pollution Bulletin, 56(12): 2027-2036. https://doi.org/10.1016/j.marpolbul.2008.08.009

Usero, J., Morillo, J. \& Gracia, I. (2005). Heavy metal concentrations in molluscs from the Atlantic coast of southern Spain. Chemosphere, $\quad \mathbf{5 9}(8)$ : 1175-1181. https://doi.org/10.1016/j.chemosphere.2004.11.089

Yildiz, H., Berber, S., Acarl, S. \& Vural, P. (2011). Seasonal variation in the condition index, meat yield and biochemical composition of the flat oyster Ostrea edulis (Linnaeus, 1758) from the Dardanelles, Turkey. Italian Journal of Animal Science, 10(1) e5: 22-26. https://doi.org/10.4081/ijas.2011.e5 